
\title{
25 Research Square \\ Effects of Freezing-Thawing Pretreatment on Anaerobic Digestion of Wheat Straw and its Kinetics Analysis
}

QIANRU ZHANG ( $\sim$ zqr.1992@163.com )

Northwest A\&F University: Northwest Agriculture and Forestry University https://orcid.org/0000-00029370-9603

\section{Yiqing Yao}

Northwest A\&F University: Northwest Agriculture and Forestry University

\section{Xinming Xi}

Northwest A\&F University: Northwest Agriculture and Forestry University https://orcid.org/0000-00030647-0284

\section{Research Article}

Keywords: Freezing-Thawing pretreatment, Anaerobic digestion, Kinetic analysis, Wheat straw

Posted Date: March 19th, 2021

DOl: https://doi.org/10.21203/rs.3.rs-233899/v1

License: (c) (i) This work is licensed under a Creative Commons Attribution 4.0 International License. Read Full License

Version of Record: A version of this preprint was published at Clean Technologies and Environmental Policy on April 24th, 2021. See the published version at https://doi.org/10.1007/s10098-021-02091-2. 


\section{Abstract}

In this study, freezing-thawing (FT) pretreatment of different freezing time and freezing temperatures was investigated to find the effect on anaerobic digestion of wheat straw (WS). The freezing temperature gradient is $-10,-20,-40$ and $-80^{\circ} \mathrm{C}$, and the freezing time gradient is $12 \mathrm{~h}, 24 \mathrm{~h}, 48 \mathrm{~h}$ and $96 \mathrm{~h}$. Total methane production exhibited a mere distance among all samples. Morphology change sculptured by SEM showed this method broken the structure of WS leaving fragments and pores in varying degrees. Three kinetic models were performed on WS to represent the behavior of experimental data. Kinetic model parameters of total methane production and lag phase time showed that logistic function model had the best fit, followed by modified Gompertz model, yet transfer function model lost efficacy in this experiment. Logistic function model was then used to reveal the influence on lag phase caused by freezing time and freezing temperature, the results implied that FT pretreatment can shorten the lag phase time of anaerobic digestion (AD), providing a $21.39 \%$ improvement under the optimal conditions of $-20^{\circ} \mathrm{C} 96 \mathrm{~h}$. The analysis of response surface regression shows that the freezing temperature has more effect on the lag phase time of anaerobic digestion than freezing time. Warmer freezing temperature of $-20^{\circ} \mathrm{C}$ do better than $-80^{\circ} \mathrm{C}$ on lag time, which can be achieved in most cold regions, so this treatment can occur naturally in such area without additional energy input.In this study, freezing-thawing (FT) pretreatment of different freezing time and freezing temperatures was investigated to find the effect on anaerobic digestion of wheat straw (WS). The freezing temperature gradient is $-10,-20,-40$ and $-80^{\circ} \mathrm{C}$, and the freezing time gradient is $12 \mathrm{~h}, 24 \mathrm{~h}, 48 \mathrm{~h}$ and $96 \mathrm{~h}$. Total methane production exhibited a mere distance among all samples. Morphology change sculptured by SEM showed this method broken the structure of WS leaving fragments and pores in varying degrees. Three kinetic models were performed on WS to represent the behavior of experimental data. Kinetic model parameters of total methane production and lag phase time showed that logistic function model had the best fit, followed by modified Gompertz model, yet transfer function model lost efficacy in this experiment. Logistic function model was then used to reveal the influence on lag phase caused by freezing time and freezing temperature, the results implied that FT pretreatment can shorten the lag phase time of anaerobic digestion (AD), providing a $21.39 \%$ improvement under the optimal conditions of $-20^{\circ} \mathrm{C} 96 \mathrm{~h}$. The analysis of response surface regression shows that the freezing temperature has more effect on the lag phase time of anaerobic digestion than freezing time. Warmer freezing temperature of $-20^{\circ} \mathrm{C}$ do better than $-80^{\circ} \mathrm{C}$ on lag time, which can be achieved in most cold regions, so this treatment can occur naturally in such area without additional energy input.

\section{Introduction}

With the increasing energy demand of developing countries like China, the problem of lacking fossil fuels is getting more and more serious. Besides, burning fossil fuels causes air pollution, which directly worsens the environment and can also result in the formation of secondary pollutants (Fan et al. 2019). Anaerobic digestion (AD), considered to be an environmental-friendly technology, which converts forestry residues and agriculture waste into methane is also net $\mathrm{CO}_{2}$ zero to the atmosphere (Zabed et al. 2020a). 
Wheat straw (WS) mainly consisting of cellulose, hemicellulose and lignin, is an easily available source at low cost, that can be used to produce acids then convert to biogas (Shen et al. 2019). However, these components of WS are closely combined with each other to form a complex three-dimensional structure on the cellular scale, making WS free from microbial attack (Kumari et al. 2018). This obstacle makes WS difficult to be degraded, hence a long lag phase due to hydrolysis (You et al. 2019;Zou et al. 2020). In most cases, hydrolysis is a rate limiting step in the AD with straw as substrate (Cornejo et al. 2019).

In the whole process, the length of lag phase time will directly affect or even determine the degree of organic matter degradation and methane production performance (Chen et al. 2020). Various pretreatment methods aim to shorten the lag phase and improve the AD efficiency of lignocellulosic biomass (Paul et al. 2018;Phuttaro et al. 2019;C. Rodriguez et al. 2017;Zou et al. 2020). Physical pretreatment usually leads to larger surface area and more porosity of substrate, thus enhances the accessibly of cellulose (Yu et al. 2019). Jackowiak et al. (2011) pretreated WS by microwave, and got the highest methane production improvement of $28 \%$, meanwhile decreased the initial lag phase of AD. With the increase of grinding degree of straw, surface area is increased and the dry anaerobic digestion started fast (Niu et al. 2012). Milling pretreatment can shorten both the digestion start-up time and the digestion time (Yu et al. 2019). Chemical pretreatment improves raw material degradation rate by breaking down the covalent bond of lignocellulose, resulting in a quick start-up time (Yu et al. 2019). Studies showed that $\mathrm{NaOH}$ pretreatment shortened the digestion time and increased the gas yield (C. Sun et al. 2017). Acid pretreatment largely disrupts the lignocellulosic matrix by cleaving glucosidic bonds, resulting in the highly conversion of polysaccharides in short time (Solarte-Toro et al. 2019). Chemical pretreatment is efficient yet usually produces toxic inhibitor, which releases pollution to the environment or increases the cost of chemical recovery (S. Tian et al. 2018). Microbiological pretreatment uses microbial such as white-rot and brown-rot fungi to produce a series of ligninolytic enzymes that modify lignin and makes lignocellulose accessible for anaerobic microbial (Zhang et al. 2019). It is a mild approach while limited by its cost (Rabemanolontsoa et al. 2016). An optimal biological pretreatment resulted in $33.07 \%$ more total biogas yield and $34.6 \%$ shorter technical digestion time compared with the untreated (Zhong et al. 2011).

Physical pretreatment is widely used in industry of AD (Cristina Rodriguez et al. 2017), while substrate always suffers a heated procedure by traditional physical pretreatment, such as liquid hot water, steam explosion, irritation even the milling (Giuliano et al. 2019). Owing to the heat, some inhibitory byproduction like furfural and hydroxymethyl furfural (HMF) may occur (Ferreira et al. 2013).

Freezing-thawing (FT) method is widely used in food industry, medical technology, pharmaceutical industry, biochemistry and microbiology to conserve proteins, tissues and cells for a long period (Karthikeyan et al. 2018;Smichi et al. 2016). Several studies indicate that FT can cause cell injuries by ice crystals (De Carvalho et al. 2020;Diak et al. 2016;Dixon et al. 2018). Hence, researchers used this method as a pretreatment way on $A D$ to destroy the structure of substrate. It can be a low-cost method to treat wastewater-grown microalgae by taking advantage of the winter season in cold-climate zones (Kinnunen et al. 2014). Montusiewicz et al. (2010) examined this method on sludge, which was 
frozen at $-25^{\circ} \mathrm{C}$ for $24 \mathrm{~h}$ and thawed at $20^{\circ} \mathrm{C}$ for $12 \mathrm{~h}$ in air. The biogas yield obtained from frozen-thawed sludge was $1.31 \mathrm{~m}^{3} \cdot \mathrm{kg}^{-1}$ of removed volatile solids (VS). FT can occur in nature; thus, this pretreatment can be applied in some countries that have low temperature circumstances without additional cost (X. R. Liu et al. 2020). In our country, the temperature in Heilongjiang Province can hit an average of $-30^{\circ} \mathrm{C}$. In northern Europe, the climate is also known for its harsh winter, where temperatures can reach $-27^{\circ} \mathrm{C}$ (Yao et al. 2020). Li et al. (2019) took corn straw for natural freezing-thawing in Beijing winter, and got an improvement in biomethane yield of $28.3 \%$ on solid: liquid ratio of $1: 6$ pretreatment group.

$A D$ is a complex process and the mechanism is difficult to be clarified owing to the effect of antagonism, synergism, acclimatization and formation of toxic compounds (Bala et al. 2019). Appropriate kinetic models can simplify and accurately explain the mechanisms in $A D$, and predict the performance of digestions under different operating conditions (Nguyen et al. 2019). Hence, it's necessary to present dynamic simulation helping us understanding the AD process after pretreatment. Different key parameters, including hydrolysis rate constant, lag phase and maximum methane yield, can be quantified by kinetic analysis, which is helpful to evaluate the behavior of $A D$ in this study (Bedoić et al. 2020). Furthermore, kinetic models offer a fast and low-cost method to predict the behavior of AD process and to design and optimize bioreactor. Appropriate kinetic models can produce reliable prediction results, which are crucial for process design and operation, and ultimately expand AD process (L. Li et al. 2018;Wang et al. 2021).

Logistic function model (LFM), modified Gompertz model (MGM) and transference function model (TFM) are commonly reported in literature for the determination of methane production (Bohutskyi et al. 2018;Q. Yu et al. 2020), and will be used in this study on WS.

The present study is invested to study the effects of FT pretreatment on AD of WS, and this method avoids by-products caused by heating in traditional physical pretreatment (Atelge et al. 2020;W. Tian et al. 2020). The $\mathrm{pH}$ value was measured to detect the stability of AD system. Methane production and methane content were calculated to find the gas properties affected by this pretreatment method. Three kinetic models were performed to reproduce experimental data and obtained a specific correlation between different variabilities. Scanning Electron Microscope (SEM) was conducted to find the structure change after different pretreatments.

\section{Materials And Methods}

\section{Raw biomass}

WS was collected from a farm near Northwest A\&F University, Yangling, China, air dried and milled to 20 mesh with a hammer mill. After then the WS was dried at $55^{\circ} \mathrm{C}$ for $48 \mathrm{~h}$ and stored in a refrigerator at $4^{\circ} \mathrm{C}$ for later use. Inoculum used in this study was obtained from a ferment pool in Henan province and preincubated by ourselves for half a month in order to minimize the residual biodegradable organic matter at mesophilic temperature. The characteristics of initial WS and inoculum are shown in Table 1. 
Table 1 Characteristics of substrate and inoculum

\begin{tabular}{lll}
\hline Parameter & WS & Inoculum \\
\hline $\mathrm{pH}$ & $\mathrm{ND}$ & $7.39 \pm 0.02$ \\
Total solid (\%) & $96.94 \pm 0.21$ & $7.05 \pm 0.47$ \\
Volatile solid (\%) & $85.04 \pm 0.47$ & $5.03 \pm 0.13$ \\
Total carbon (\%) & $37.63 \pm 0.64$ & $34.89 \pm 0.81$ \\
Total nitrogen (\%) & $0.91 \pm 0.69$ & $2.18 \pm 0.14$ \\
Cellulose (\%) & $31.07 \pm 1.29$ & $\mathrm{ND}$ \\
Hemicellulose (\%) & $21.47 \pm 0.89$ & $\mathrm{ND}$ \\
Lignin (\%) & $27.85 \pm 0.20$ & $\mathrm{ND}$ \\
\hline
\end{tabular}

ND: not determineded.

The \% content of parameters were calculated based on dry mass.

\section{Pretreatment of WS}

For less water content biomass (Ge et al. 2016), FT pretreatment includes a presoak step to make water permeate. Freezing temperature investigated in this study was $-10^{\circ} \mathrm{C},-20^{\circ} \mathrm{C},-40^{\circ} \mathrm{C}$ and $-80^{\circ} \mathrm{C}$, four freezing time of $12 \mathrm{~h}, 24 \mathrm{~h}, 48 \mathrm{~h}$ and $96 \mathrm{~h}$ were conducted by orthogonal experiment. Same weighted samples of WS and deionized water were put into sealing bags, with the solid to liquid ratio of $1: 8 \mathrm{w} / \mathrm{w}$, based on the dry weight of WS. Every experimental sample was presoaked at room temperature for 8 hours after shaking, then put into four refrigerators together. Each group was taken out at set time, and thawed for 8 hours in air (around $20^{\circ} \mathrm{C}$ ). Before $A D$, all samples were filtered and oven dried at $55^{\circ} \mathrm{C}$ for $48 \mathrm{~h}$.

\section{Anaerobic digestion of WS}

In this study, the $A D$ was conducted in batch. Every $A D$ assay was taken place in a $500 \mathrm{~mL}$ serum bottle with $300 \mathrm{~mL}$ working volume in order to provide enough headspace for gas production. The organic loading rate of each bottle was $35 \mathrm{~g} / \mathrm{L}$ (VS), substrate to inoculum rate was 1 , based on VS. Since WS has a high $\mathrm{C} / \mathrm{N}$ ratio, the lack of nitrogen may limit the final methane production obtained in biochemical methane potential. Thus, the same appropriate dose of ammonia chloride $\left(\mathrm{NH}_{4} \mathrm{Cl}\right)$ was added to each bottle to get the best $\mathrm{C} / \mathrm{N}$ of $25: 1$. After being filled with deionized water, all bottles were sealed with a butyl rubber septum and an aluminum crimp. The headspace of each bottle was flushed with pure $\mathrm{N}_{2}$ for 2 mins. Then all bottles were put into an incubator at $37 \pm 1{ }^{\circ} \mathrm{C}$ for AD. The unpretreated WS was prepared and run as control, and the inoculum only was also performed to detect the methanogenic activity of inoculum. Different pretreatment conditions were carried out in duplicate, and the data were analyzed by the mean values of two measurements. The experiment was conducted for 29 days. 


\section{Analytical methods}

For WS and inoculum, the total solids (TS) and volatile solids (VS) were determined according to the American Public Health Association (APHA) Standard Methods (1998). The total carbon (TC) and total nitrogen (TN) were determined by the Vario EL/micro cube elemental analyzer (Elementar, Germany). The $\mathrm{pH}$ value was measured by a $\mathrm{pH}$ meter PHSJ-4A twice a day. Biogas was collected in aluminum foil bags and calculated by the method of water displacement every other day, and the total biogas volume was measured at the end of digestion. Methane content was measured by a gas chromatograph (Shimadzu GC-2014, Japan) with a TCD detector, using helium as the carrier gas, and the initial oven and detector temperature were set at $220^{\circ} \mathrm{C}$ and $60^{\circ} \mathrm{C}$. Methane production was defined as the volume of methane gas produced per gram of VS of biomass added as initial substrate. Structure change of each sample was observed by scanning electron microscopy Model S-3400N (Hitachi, Japan).

\section{Kinetic models}

In this study, the AD of WS was simulated by modified Gompertz model (MGM), logistic function model (LFM) and transference function model (TFM). The TFM was generally used for characterizing the linearly growth of inoculum, and the MGM and the LFM was to estimate specific methanogenic activity and lag period as a sigmoidal pattern (Kainthola et al. 2019;D. Yu et al. 2020). Three models are shown in Eqs. (1)-(3) (Panigrahi et al. 2020):

\section{Modified Gompertz model (MGM) :}

$$
B=B_{0} \cdot \exp \quad\left\{-\exp \left[\frac{R_{m} \cdot \boldsymbol{e}}{B_{0}}(\lambda-t)+1\right]\right\}
$$

Logistic function model (LFM):

$$
B=\frac{B_{0}}{1+\exp \left[\frac{4 \cdot R_{m}(\lambda-t)}{B_{0}}+2\right]}
$$

Transference function model (TFM):

$$
B=B_{0} \cdot\left\{1-\exp \left[-\frac{R_{m}(t-\lambda)}{B_{0}}\right]\right\}
$$

where, $B$ is the accumulated methane production $(\mathrm{mL})$ at time $t(\mathrm{~d}), B_{0}$ is the potential methane production ( $\mathrm{mL} / \mathrm{g} V \mathrm{~S}), R_{m}$ is maximum rate of methane production $\left.(\mathrm{mL} / \mathrm{g} \mathrm{VS} / \mathrm{d})\right), \lambda$ is the lag phase parameter (d), $t$ is the time (d), and $\mathbf{e}$ is the base of a natural constant (2.7183). 
Using the correlation coefficients $\left(\mathrm{R}^{2}\right)$ and Root Mean Square Error (RMSE) as indicators for model evaluation:

(1) $R^{2}$ is known as the goodness of fit index.

(2) RMSE is defined as the standard deviation between the predicted and experimental values, a lower RMSE indicating a better fit (Y. Li et al. 2018).

\section{Statistical analysis}

Statistical analysis, graphing and fitting were finished by Origin Pro 9.1 (Origin Lab, USA). This software was also used to fit the quadratic polynomial models. Significant difference and coefficients analysis of the kinetic equation were carried out using the analysis of variance (ANOVA) $(p<0.05)$.

\section{Results And Discussion}

\section{$\mathrm{pH}$ value and stability}

The $\mathrm{pH}$ value represents an important parameter of $\mathrm{AD}$ which indirectly reflects the stability of the process (Yu et al. 2019). Fig. 1 shows the variation of $\mathrm{pH}$ value on each assay in a function of digestion time. The $\mathrm{pH}$ value of inoculum only conducted as blank control was around 7.5 in the whole experimental period. For pretreated WS assays, they began with almost the same $\mathrm{pH}$ value around 7.7, while the untreated WS had an initial $\mathrm{pH}$ around 7.5 same with inoculum only. There was a drop of $\mathrm{pH}$ value in all assays except the inoculum control in the first period. The lowest $\mathrm{pH}$ value of pretreated WS came to 6.22 on the 7th day performed on $-10^{\circ} \mathrm{C} 48 \mathrm{~h}$ pretreated WS, merely higher when compared with untreated WS who owned its lowest $\mathrm{pH}$ of 6.12 on the same day. The drop of all assays due to the digestion of easily available organic matters, which generates the volatile fatty acids (VFA). Meanwhile, the acidogenic microorganisms are more than methanogenic microorganisms leading to the accumulation of VFA and the drop of $\mathrm{pH}$ value (Veluchamy et al. 2018). After the consumption of VFA, the $\mathrm{pH}$ value increased directly and reached a rather stable value around 7 , which is within the best suitable range of 6.8-7.2 for methanogens' growth and activity (Savoo et al. 2018). There was no significant difference in $\mathrm{pH}$ value between different pretreated $\mathrm{WS}$, and the $\mathrm{pH}$ value was less fluctuating in every pretreated assay during the methane-producing period, ranging from 6.80-7.22. FT pretreatment increased the surface area of substrate due to the shear force of ice crystals (Gruber-Brunhumer et al. 2016). Usually, increasing surface area means the acceleration of hydrolysis, which leads to a sever accumulation of VFA, and the $\mathrm{pH}$ value should be lower than untreated assay, or even acidification (Dumas et al. 2015; Veluchamy et al. 2018). Just like the result obtained by Veluchamy et al. (2018), who pretreated lignocellulose biomass and got a deeper drop on pretreated biomass after electrohydrolysis. Whereas, the observation in this study contrasted with theirs. The lowest $\mathrm{pH}$ value of pretreated WS was higher than untreated WS, and it came up soon without outside operating. This indicates that the anaerobic microbial community establishes balance by adjusting itself, implying a better buffer capacity of pretreated system is obtained (W. Li et al. 2018;Shen et al. 2019). 


\section{Methane production properties}

The effect of FT pretreatment on AD of WS was determined by biogas production properties. In this study, methane content, total methane production and daily methane production were estimated.

\section{Methane content}

The biogas quality was justified by methane content. Biogas is mainly composed of $55-70 \% \mathrm{CH}_{4}$ and 30 $45 \% \mathrm{CO}_{2}$, and small quantities of other gases (Zabed et al. 2020b). In this work, the content of other gases in the biogas was measured in ppm, so we assumed that methane and carbon dioxide accounted for $100 \%$ of the total biogas. This hypothesis is similar to former study which assumption that the biogas is $100 \%$ content of methane and carbon dioxide while is hydrogen-free (Bedoić et al. 2019). In this study, the variations of methane content are presented in Fig. 2, which reached more than $60 \%$ after the system had stabilized. No obvious distinction was checked from FT pretreated WS in comparison with untreated WS. These results indicate that the distinction of methane content on WS via FT pretreatment influences to a minor extent. This conclusion is similar to Montusiewicz et al. (2010), who got methane content of $61.5 \%$ and $63.0 \%$ on mixed (primary and waste) sewage sludge via freezing-thawing pretreatment, showing only a slight distinction of $1.5 \%$.

\section{Methane production}

Methane production of all pretreated WS is exhibited in Fig. 3. Besides inoculum only, every pretreated WS has a similar methane production behavior including the untreated WS. During the initial 7 days, the curve in Fig. $3 a$ is smooth and climbs slowly owing to the low methane production. This observation corresponds to the decline in $\mathrm{pH}$ value in the first 7 days.

After the first few days, the methane production increased exponentially then slowed down to a plateau, announcing the end of digestion. The untreated WS got the total methane production of $171.30 \pm 2.52$ $\mathrm{mL} / \mathrm{g}$ VS, which was slightly higher $(\mathrm{p}<0.05)$ than all pretreated WS except the sample pretreated at $-40^{\circ} \mathrm{C}$ for $24 \mathrm{~h}$, which got the highest methane production of $189.20 \pm 9.33 \mathrm{~mL} / \mathrm{g} \mathrm{VS}$ among all.

Table 2 Summary of the results (average values \pm standard deviation) 


\begin{tabular}{|c|c|c|}
\hline Sample & TS $₫ \% \square$ & VS $\% \square$ \\
\hline Untreated & $96.94 \pm 0.21$ & $85.04 \pm 0.47$ \\
\hline$-10^{\circ} \mathrm{C} 12 \mathrm{~h}$ & $96.28 \pm 0.13$ & $83.99 \pm 0.37$ \\
\hline$-10^{\circ} \mathrm{C} 24 \mathrm{~h}$ & $96.41 \pm 0.31$ & $83.45 \pm 0.71$ \\
\hline$-10^{\circ} \mathrm{C} 48 \mathrm{~h}$ & $96.61 \pm 0.17$ & $83.66 \pm 0.44$ \\
\hline$-10^{\circ} \mathrm{C} 96 \mathrm{~h}$ & $96.21 \pm 0.33$ & $83.38 \pm 0.39$ \\
\hline$-20^{\circ} \mathrm{C} 12 \mathrm{~h}$ & $96.11 \pm 0.37$ & $83.11 \pm 0.29$ \\
\hline$-20^{\circ} \mathrm{C} 24 \mathrm{~h}$ & $96.42 \pm 0.16$ & $83.44 \pm 0.19$ \\
\hline$-20^{\circ} \mathrm{C} 48 \mathrm{~h}$ & $96.41 \pm 0.39$ & $83.04 \pm 0.87$ \\
\hline$-20^{\circ} \mathrm{C} 96 \mathrm{~h}$ & $96.33 \pm 0.17$ & $83.27 \pm 0.43$ \\
\hline$-40^{\circ} \mathrm{C} 12 \mathrm{~h}$ & $96.65 \pm 0.17$ & $83.5 \pm 0.14$ \\
\hline$-40^{\circ} \mathrm{C} 24 \mathrm{~h}$ & $96.15 \pm 0.45$ & $83.48 \pm 0.25$ \\
\hline$-40^{\circ} \mathrm{C} 48 \mathrm{~h}$ & $96.52 \pm 0.08$ & $83.61 \pm 0.71$ \\
\hline$-40^{\circ} \mathrm{C} 96 \mathrm{~h}$ & $96.17 \pm 0.40$ & $83.16 \pm 0.46$ \\
\hline$-80^{\circ} \mathrm{C} 12 \mathrm{~h}$ & $95.72 \pm 0.20$ & $83.35 \pm 0.45$ \\
\hline$-80^{\circ} \mathrm{C} 24 \mathrm{~h}$ & $96.00 \pm 0.10$ & $83.27 \pm 0.56$ \\
\hline$-80^{\circ} \mathrm{C} 48 \mathrm{~h}$ & $96.51 \pm 0.12$ & $83.24 \pm 0.45$ \\
\hline$-80^{\circ} \mathrm{C} 96 \mathrm{~h}$ & $96.00 \pm 0.28$ & $83.19 \pm 0.69$ \\
\hline Inoculum & $5.03 \pm 0.13$ & $7.05 \pm 0.47$ \\
\hline
\end{tabular}

The scarcely decline in total methane production after FT pretreatment may be due to the loss of organic matters. During FT pretreatment, a strong mechanical force caused by ice crystals tears WS and makes organic matters released, some of which are flushed by water after thawing. As shown in Table 2, the VS of all pretreated samples decreased, with the highest drop of $2.41 \%$. It is reported that different pretreatments lead to the losses of mass (Bolado-Rodriguez et al. 2016). Long-term FT resulted in the loss of dry matter (Li et al. 2019). Kumar et al. (2019) concludes that VS loss resulting from pretreatment offsets the improvement in biogas production. Rahman et al. (2018) reported a considerable loss of methane to the atmosphere owing to the degradation of VS. The mass loss of around $20 \%$ TS for fungal pretreated WS was observed during fungi growth on miscanthus pellets, and during WS pretreatment, a $10 \%$ decrease was observed in the final methane production yield (Rouches et al. 2019).

It can be concluded that the FT pretreatment has little effect on total methane production of WS, and various pretreatment conditions have merely distance on this parameter (Fig. 3b). The same result of no higher methane yields can be found on WS suffering steam-exploded pretreatment, and sever pretreated condition did not result in higher methane yields except stable (Risberg et al. 2013). Theuretzbacher et al. 
(2015) steam exploded wheat straw to AD, and also found no significant difference in methane production.

\section{Daily methane production}

Daily methane production of all WS in the function of time has similar behavior and shows several peaks during the $A D$ in Fig. 4 (a-c).

The first peak of all performed WS was achieved on the 9th or 11th day, which came later after the lowest $\mathrm{pH}$ value occurred on the 7th day, responding for the VFA beginning to be consumed by methanogenic microorganisms. WS pretreated by $-80^{\circ} \mathrm{C} 48 \mathrm{~h},-20^{\circ} \mathrm{C} 96 \mathrm{~h},-20^{\circ} \mathrm{C} 48 \mathrm{~h},-40^{\circ} \mathrm{C} 96 \mathrm{~h}$, and $-80^{\circ} \mathrm{C} 96 \mathrm{~h}$ achieved their own first peak on the 9th day. It can be found that this enhancement occurred on longer freezing time pretreated WS. This observation suggests that the FT pretreatment could ahead daily methane production peak of AD on WS at a longer freezing time. Two days later, the first peak of the remaining WS simultaneously appeared with different daily methane production. The $-80^{\circ} \mathrm{C} 48 \mathrm{~h}$ pretreated WS has the highest daily methane production of $33.23 \pm 0.33 \mathrm{~mL} / \mathrm{g} \mathrm{VS}$ among all, and the distance among different pretreatment conditions were not significant. The enhancement in the daily methane yield could be related to the increase of the more accessible fraction of substrate. The compact structure of WS was disrupted by ice crystalline resulting from FT, which subsequently increased the accessible surface area of the biomass (Rooni et al. 2017). Gu et al. (2015) found that pretreated rice straw produced more biogas in the initial period owing to the peak of daily biogas yield was ahead of schedule.

Three-quarters of pretreated WS stopped producing methane on the 27th day, which is two days earlier than untreated WS. This indirectly implies that FT can improve the efficiency of AD by shortening digestion time (Jeong et al. 2016;X. Y. Liu et al. 2008;Qi et al. 2020).

\section{Scanning electron microscope (SEM)}

SEM was conducted to find the structural change on every WS after being subjected to FT pretreatment at $2000 \times$ magnification. In Fig. 5, the surface of untreated WS is smooth and compact. After FT pretreatment, cracks occur, breaking the complete surface and exposing some interior space of WS. As pretreatment condition aggravates, the structure loosens, and more pores and cracks appear which promotes the increasing in surface area. Furthermore, the pore size can be found to get larger with the increasing in pretreatment conditions. The phenomenon of peel-off skin can be seen on $-80^{\circ} \mathrm{C} 96 \mathrm{~h}$ pretreated WS, exposing interior space totally. This pretreatment can efficiently increase the surface area of WS and make the substrate more available for anaerobic microorganisms. The increase in accessible surface area is caused by the ice crystals that form when the water penetrating the WS during the presoaking stage freezes, breaking the surface of the straw biomass and making the WS more digestible.

\section{Kinetic analysis}

Model analysis

Page 10/30 
In this study, three models were modified to take the biological parameter into consideration, based on the growth of microorganisms rather than the consumption rate of substrate (Veluchamy et al. 2018;Ware et al. 2017) .

Kinetic parameters predicted from three models based on batch experiment are shown in Table 3. In both LFM and MGM, high $\mathrm{R}^{2}$ and limited RMSE were obtained, indicating that these two models gave goodness fit between experimental data and predicted value. Furthermore, the comparative higher $\mathrm{R}^{2}$ attained from LFM implies that LFM provides a better fit for kinetic study of this assay. Unexpectedly, TFM could not provide a good match with the experimental data in all cases. The similar unsatisfactory fit of the TFM was also obtained by Huiliñir et al. (2014) and Rajput et al. (2018). Though, the high $\mathrm{R}^{2}$ was obtained, yet the RMSE was extremely large and the predicted total methane production potential $B_{0}$ values are considerably higher than experimental data. Bohutskyi et al. (2018) reported the modified Gompertz model was able to provide an accurate description for anaerobic digestion with high $\mathrm{R}^{2}$ and the lowest RMSE among all models which provided satisfactory fitting $\left(R^{2} \geq 0.9\right)$ for biogas and methane production. This unsatisfactory fit by the TFM resulted from its own limited definition. This model predicts the maximum methane production based only on accumulated methane production over time (Veluchamy et al. 2017). Martín et al. (2018) also reported that LFM had a better fit with the experimental data than MGM in AD processes.

Table 3 Experimental data and predicted values and goodness of fit from the evaluated models. 


\begin{tabular}{|c|c|c|c|c|c|c|c|}
\hline $\begin{array}{c}\text { Pretreatment } \\
\text { condition }\end{array}$ & Model & $\begin{array}{c}\mathrm{B}_{0}(\mathrm{~mL} \\
\mathrm{CH} 4 / \mathrm{g} \mathrm{VS})\end{array}$ & $\begin{array}{c}\mathrm{R}_{\mathrm{m}}(\mathrm{mL} \\
\mathrm{CH} 4 / \mathrm{g} \mathrm{VS})\end{array}$ & $\lambda(d)$ & $\begin{array}{c}\text { Experimental (mL } \\
\mathrm{CH} 4 / \mathrm{g} \text { VS) }\end{array}$ & $\mathrm{R}^{2}$ & RMSE \\
\hline \multirow[t]{3}{*}{ Untreated } & $\begin{array}{l}\text { Gompertz } \\
\text { model }\end{array}$ & 191.536 & 11.463 & 7.116 & $171.30 \pm 2.52$ & 0.996 & 20.236 \\
\hline & Logistic model & 176.879 & 12.355 & 7.986 & & 0.997 & 5.579 \\
\hline & $\begin{array}{c}\text { Transference } \\
\text { model }\end{array}$ & $8,599.555$ & 7.515 & 3.303 & & 0.959 & $8.428 E+03$ \\
\hline \multirow[t]{3}{*}{$-10^{\circ} \mathrm{C} 12 \mathrm{~h}$} & $\begin{array}{c}\text { Gompertz } \\
\text { model }\end{array}$ & 183.118 & 10.381 & 6.227 & $161.66 \pm 2.75$ & 0.994 & 22.536 \\
\hline & Logistic model & 168.886 & 11.157 & 7.117 & & 0.996 & 7.182 \\
\hline & $\begin{array}{c}\text { Transference } \\
\text { model }\end{array}$ & $1,088.673$ & 7.550 & 2.899 & & 0.962 & $4.212 \mathrm{E}+13$ \\
\hline \multirow[t]{3}{*}{$-10^{\circ} \mathrm{C} 24 \mathrm{~h}$} & $\begin{array}{l}\text { Gompertz } \\
\text { model }\end{array}$ & 182.045 & 10.110 & 6.052 & $158.44 \pm 5.78$ & 0.989 & 22.602 \\
\hline & Logistic model & 167.125 & 11.044 & 7.086 & & 0.994 & 7.179 \\
\hline & $\begin{array}{c}\text { Transference } \\
\text { model }\end{array}$ & 897.485 & 7.555 & 2.814 & & 0.957 & $4.342 \mathrm{E}+13$ \\
\hline \multirow[t]{3}{*}{$-10^{\circ} \mathrm{C} 48 \mathrm{~h}$} & $\begin{array}{l}\text { Gompertz } \\
\text { model }\end{array}$ & 193.573 & 10.027 & 5.571 & $167.19 \pm 4.22$ & 0.994 & 22.533 \\
\hline & Logistic model & 176.262 & 10.879 & 6.579 & & 0.995 & 7.067 \\
\hline & $\begin{array}{c}\text { Transference } \\
\text { model }\end{array}$ & 954.479 & 7.831 & 2.692 & & 0.969 & $4.484 \mathrm{E}+13$ \\
\hline \multirow[t]{3}{*}{$-10^{\circ} \mathrm{C} 96 \mathrm{~h}$} & $\begin{array}{l}\text { Gompertz } \\
\text { model }\end{array}$ & 162.567 & 9.106 & 6.048 & $143.36 \pm 0.43$ & 0.993 & 22.233 \\
\hline & Logistic model & 150.042 & 9.780 & 6.962 & & 0.993 & 6.902 \\
\hline & $\begin{array}{c}\text { Transference } \\
\text { model }\end{array}$ & 764.334 & 6.877 & 2.974 & & 0.964 & $4.642 \mathrm{E}+13$ \\
\hline \multirow[t]{3}{*}{$-20^{\circ} \mathrm{C} 12 \mathrm{~h}$} & $\begin{array}{l}\text { Gompertz } \\
\text { model }\end{array}$ & 189.566 & 10.645 & 6.270 & $166.93 \pm 0.52$ & 0.994 & 22.448 \\
\hline & Logistic model & 174.656 & 11.411 & 7.147 & & 0.995 & 6.919 \\
\hline & $\begin{array}{c}\text { Transference } \\
\text { model }\end{array}$ & 1,359.096 & 7.674 & 2.926 & & 0.962 & $4.817 \mathrm{E}+13$ \\
\hline \multirow[t]{3}{*}{$-20^{\circ} \mathrm{C} 24 \mathrm{~h}$} & $\begin{array}{l}\text { Gompertz } \\
\text { model }\end{array}$ & 187.257 & 10.211 & 6.234 & $165.63 \pm 4.88$ & 0.996 & 22.433 \\
\hline & Logistic model & 171.431 & 10.982 & 7.137 & & 0.995 & 6.847 \\
\hline & $\begin{array}{c}\text { Transference } \\
\text { model }\end{array}$ & $1,830.238$ & 7.385 & 3.003 & & 0.969 & $5.014 \mathrm{E}+13$ \\
\hline \multirow[t]{3}{*}{$-20^{\circ} \mathrm{C} 48 \mathrm{~h}$} & $\begin{array}{l}\text { Gompertz } \\
\text { model }\end{array}$ & 189.530 & 10.562 & 5.867 & $166.35 \pm 1.29$ & 0.991 & 22.505 \\
\hline & Logistic model & 174.704 & 11.441 & 6.853 & & 0.993 & 6.934 \\
\hline & $\begin{array}{l}\text { Transference } \\
\text { model }\end{array}$ & 735.889 & 8.188 & 2.886 & & 0.961 & $5.237 \mathrm{E}+13$ \\
\hline \multirow[t]{3}{*}{$-20^{\circ} \mathrm{C} 96 \mathrm{~h}$} & $\begin{array}{l}\text { Gompertz } \\
\text { model }\end{array}$ & 185.073 & 10.528 & 5.377 & $164.82 \pm 3.56$ & 0.990 & 22.436 \\
\hline & Logistic model & 172.213 & 11.253 & 6.278 & & 0.991 & 6.776 \\
\hline & $\begin{array}{c}\text { Transference } \\
\text { model }\end{array}$ & 489.884 & 8.721 & 2.716 & & 0.962 & $5.492 \mathrm{E}+13$ \\
\hline \multirow[t]{3}{*}{$-40^{\circ} \mathrm{C} 12 \mathrm{~h}$} & $\begin{array}{l}\text { Gompertz } \\
\text { model }\end{array}$ & 186.621 & 10.403 & 6.618 & $163.83 \pm 2.30$ & 0.995 & 22.665 \\
\hline & Logistic model & 171.255 & 11.173 & 7.507 & & 0.994 & 6.704 \\
\hline & $\begin{array}{c}\text { Transference } \\
\text { model }\end{array}$ & 3863.404 & 7.238 & 3.190 & & 0.965 & $5.789 \mathrm{E}+13$ \\
\hline \multirow[t]{3}{*}{$-40^{\circ} \mathrm{C} 24 \mathrm{~h}$} & $\begin{array}{l}\text { Gompertz } \\
\text { model }\end{array}$ & 231.112 & 10.753 & 6.889 & $189.20 \pm 9.33$ & 0.996 & 22.650 \\
\hline & Logistic model & 201.485 & 11.860 & 7.983 & & 0.996 & 6.608 \\
\hline & $\begin{array}{l}\text { Transference } \\
\text { model }\end{array}$ & $6.68 E+14$ & 7.940 & 3.566 & & 0.972 & $6.140 \mathrm{E}+13$ \\
\hline$-40^{\circ} \mathrm{C} 48 \mathrm{~h}$ & Gompertz & 187.475 & 10.588 & 6.537 & $165.78 \pm 1.50$ & 0.996 & 17.087 \\
\hline
\end{tabular}


model

\begin{tabular}{|c|c|c|c|c|c|c|c|}
\hline & Logistic model & 172.341 & 11.401 & 7.440 & & 0.996 & 4.811 \\
\hline & $\begin{array}{c}\text { Transference } \\
\text { model }\end{array}$ & $2,029.625$ & 7.463 & 3.142 & & 0.965 & $3.308 E+03$ \\
\hline \multirow[t]{3}{*}{$-40^{\circ} \mathrm{C} 96 \mathrm{~h}$} & $\begin{array}{c}\text { Gompertz } \\
\text { model }\end{array}$ & 180.528 & 10.629 & 6.142 & $164.00 \pm 1.70$ & 0.997 & 16.191 \\
\hline & Logistic model & 167.682 & 11.346 & 6.980 & & 0.995 & 4.453 \\
\hline & $\begin{array}{c}\text { Transference } \\
\text { model }\end{array}$ & 720.785 & 8.020 & 3.095 & & 0.967 & $3.492 \mathrm{E}+03$ \\
\hline \multirow[t]{3}{*}{$-80^{\circ} \mathrm{C} 12 \mathrm{~h}$} & $\begin{array}{c}\text { Gompertz } \\
\text { model }\end{array}$ & 166.332 & 10.722 & 6.310 & $152.81 \pm 1.04$ & 0.996 & 16.123 \\
\hline & Logistic model & 156.538 & 11.315 & 7.028 & & 0.998 & 4.592 \\
\hline & $\begin{array}{c}\text { Transference } \\
\text { model }\end{array}$ & 529.361 & 7.871 & 2.922 & & 0.956 & $3.817 E+03$ \\
\hline \multirow[t]{3}{*}{$-80^{\circ} \mathrm{C} 24 \mathrm{~h}$} & $\begin{array}{c}\text { Gompertz } \\
\text { model }\end{array}$ & 172.073 & 11.699 & 7.321 & $158.23 \pm 2.65$ & 0.996 & 16.710 \\
\hline & Logistic model & 162.427 & 12.276 & 7.983 & & 0.997 & 4.783 \\
\hline & $\begin{array}{c}\text { Transference } \\
\text { model }\end{array}$ & $1,087.616$ & 7.575 & 3.348 & & 0.950 & $4.263 \mathrm{E}+03$ \\
\hline \multirow[t]{3}{*}{$-80^{\circ} \mathrm{C} 48 \mathrm{~h}$} & $\begin{array}{c}\text { Gompertz } \\
\text { model }\end{array}$ & 175.986 & 10.785 & 5.713 & $160.92 \pm 0.06$ & 0.993 & 17.178 \\
\hline & Logistic model & 165.519 & 11.327 & 6.455 & & 0.991 & 4.730 \\
\hline & $\begin{array}{c}\text { Transference } \\
\text { model }\end{array}$ & 455.735 & 8.658 & 2.902 & & 0.961 & $4.875 E+03$ \\
\hline \multirow[t]{3}{*}{$-80^{\circ} \mathrm{C} 96 \mathrm{~h}$} & $\begin{array}{c}\text { Gompertz } \\
\text { model }\end{array}$ & 184.983 & 11.253 & 5.979 & $169.21 \pm 2.06$ & 0.997 & 18.142 \\
\hline & Logistic model & 173.062 & 11.905 & 6.745 & & 0.995 & 4.794 \\
\hline & $\begin{array}{c}\text { Transference } \\
\text { model }\end{array}$ & 578.754 & 8.668 & 2.971 & & 0.965 & $5.967 E+03$ \\
\hline
\end{tabular}

In all of the treated WS, the total methane production predicted by the kinetics models was higher than that of the experimental data. Indeed, no significant difference existed between each pretreatment in this parameter following experimental data. This behavior was replicated in the curve shown in Fig. 6 (a-c). In Fig. $6 c$, the trend of methane production seems to be linear, for TFM considers only the exponential and stationary stages in the production of gas, and regards lag phase close to zero (Huiliñir et al. 2014).

The parameter $R_{m}$ was almost consistent for all treated WS in the same model, and no significant difference was found between MGM and LFM $(\mathrm{p}<0.05)$. The $R_{m}$ in TFM is much lower than that in other two models, and still no difference was noted among different treatments.

An important parameter $\lambda$ was greatly improved. The maximum improvement in $\lambda$ obtained from LFM was $21.39 \%$ on $-20^{\circ} \mathrm{C} 96 \mathrm{~h}$ pretreated WS, and the improvement in MGM was $24.43 \%$ in the same pretreatment condition; further, an $18.50 \%$ improvement in TFM was found on $-10^{\circ} \mathrm{C} 48 \mathrm{~h}$ pretreated WS. Numerous studies have identified an enhance in $\lambda$ by different pretreatment on wheat straw (T. Liu et al. 2019;Rajput et al. 2018;Veluchamy et al. 2017). Results obtained from both experiment and kinetics models are coincidence to what reported by Kinnunen et al. (2014). The researcher pointed that FT pretreatment accelerated the substrate's degradation, but did not necessarily enhance the overall methane production.

In general, the FT exerts a good effect on the lag phase, which can influence the batch AD that is typically operated at 20-30 days. 


\section{Effects of freezing time and freezing temperature on the lag phase}

The effects of two variables of freezing time and freezing temperature on lag phase are illustrated in the three-dimensional response surface plot described in Fig. 7. The red area corresponds to the poor pretreatment condition of long lag phase time on WS, and the blue area shows the optimal pretreatment conditions. As the figure shows, the lag phase time of AD on WS is relatively short under the condition of longer freezing time, and this shortening in lag phase time is more obvious at warmer temperatures.

When the freezing temperature was increased from $-80^{\circ} \mathrm{C}$ to $-10^{\circ} \mathrm{C}$, the lag phase was shortened from $6.745 \mathrm{~d}$ to $6.579 \mathrm{~d}$. Moreover, the freezing time was prolonged from $12 \mathrm{~h}$ to $96 \mathrm{~h}$, and the lag phase was shortened from $7.174 \mathrm{~d}$ to $6.278 \mathrm{~d}$. At lower freezing temperatures, the freezing time was more sensitive to lag phase. With the interaction of warm freezing temperature and long freezing time, the lag phase was reduced from $7.983 \mathrm{~d}$ to $6.278 \mathrm{~d}$. It can be concluded from this experiment that, FT pretreatment on WS for $A D$ had a positive effect on lag phase time, and both freezing time and freezing temperature facilitated the shortening of the lag phase. A relatively shorter lag phase tends to occur in longer freezing time pretreated conditions. Warmer freezing temperatures also have a strong influence on lag phase. In contrast, cold freezing temperatures and short freezing time have less of an effect on the lag phase.

In general, warmer freezing temperatures cause higher inactivation of cells (Gao et al. 2006). It implies slower freezing rates (warmer freezing temperatures), which effectively destroy structures, may be responsible for such an effect (F. Sun et al. 2018). Besides, the viability of cells gradually decreases as the freezing time increases, with a longer freezing time, the cells can reach a higher inactivation rate (Phalakornkule et al. 2017). Similarly, a longer freezing time increases the degree of damage to the straw structure, thus increasing the accessible surface area to methanogenic microorganisms and shortening the lag phase.

\section{Influence of freezing time on the lag phase of $A D$}

Pretreatment methods of lignocellulosic biomass conducted on AD can be costly, and therefore any kinetic improvements attained via pretreatment can benefit $A D$ and cut unnecessary costs at industrial level (Shetty et al. 2017). As was noted above, freezing time has more of an impact on the lag phase than freezing temperature. To find the specific relationship between freezing time and lag phase, further give a guidance in industry, Fig. 8 (a-c) is performed.

Negative correlation was found from three models by derived quadratic polynomial models. The specific relationship between two variables could be elaborated by functions shown in Fig. 8 . It can be seen from the figure that the decrease of lag phase time is not completely linear with the increase of freezing time. The lag phase time of $96-\mathrm{h}$ group was longer than that of 48-h group. These model results show the optimal conditions and avoid the waste of energy.

\section{Conclusions}


This study investigated the effect of FT pretreatment on AD of WS. This pretreatment method is novel and has been less investigated on lignocellulosic biomass for biomass conversion by far. However, no significant improvement in total methane production or methane content was observed after FT pretreatment. The simulation results obtained from three kinetic models: LFM, MGM and TFM showed a short lag phase during the start-up stage after FT pretreatment, which was consistent with the experimental data, thus improving the AD efficiency. The optimal improvement in the lag phase occurred at warmer freezing temperatures and longer freezing times. The largest enhancement in lag phase is $21.39 \%$ obtained from LFM, and $24.43 \%$ from MGM under the same condition of $-20^{\circ} \mathrm{C} 96 \mathrm{~h}$. With respect to the lag phase, freezing time is more significant than freezing temperature. The $29-\mathrm{d}$ assay was stable after being fed with FT pretreated WS. Loose and fragmented structures were found in every pretreated WS, which resulted in a larger surface area that promoted AD.

\section{Declarations}

Funding: This research work was supported by Shaanxi Youth Thousand Talents Project (A279021901), Key Research and Development Project of Shaanxi Province (2020NY-114), Northwest A \& F University Young Talent Project (Z111021902).

\section{References}

Atelge, M R, Atabani, A E, Banu, J R, Krisa, D, Kaya, M, Eskicioglu, C, Kumar, G, Lee, C, Yildiz, Y Ş, Unalan, S, Mohanasundaram, R,Duman, $F$ (2020) A critical review of pretreatment technologies to enhance anaerobic digestion and energy recovery. Fuel 270: 117494.

Bala, R, Gupta, G K, Dasgupta, B V,Mondal, M K (2019) Pretreatment optimisation and kinetics of batch anaerobic digestion of liquidised OFMSW treated with $\mathrm{NaOH}$ : Models verification with experimental data. J Environ Manage 237: 313-321.

Bedoić, R, Čuček, L, Ćosić, B, Krajnc, D, Smoljanić, G, Kravanja, Z, Ljubas, D, Pukšec, T,Duić, N (2019) Green biomass to biogas - A study on anaerobic digestion of residue grass. Journal of Cleaner Production 213: 700-709.

Bedoić, R, Špehar, A, Puljko, J, Čuček, L, Ćosić, B, Pukšec, T,Duić, N (2020) Opportunities and challenges: Experimental and kinetic analysis of anaerobic co-digestion of food waste and rendering industry streams for biogas production. Renewable and Sustainable Energy Reviews 130: 109951.

Bohutskyi, P, Phan, D, Kopachevsky, A M, Chow, S, Bouwer, E J,Betenbaugh, M J (2018) Synergistic codigestion of wastewater grown algae-bacteria polyculture biomass and cellulose to optimize carbon-tonitrogen ratio and application of kinetic models to predict anaerobic digestion energy balance. Bioresource Technology 269: 210-220. 
Bolado-Rodriguez, S, Toquero, C, Martin-Juarez, J, Travaini, R,Garcia-Encina, P A (2016) Effect of thermal, acid, alkaline and alkaline-peroxide pretreatments on the biochemical methane potential and kinetics of the anaerobic digestion of wheat straw and sugarcane bagasse. Bioresour Technol 201: 182-190.

Chen, Y, Yang, H, Zou, H, Sun, T, Li, M, Zhai, J, He, Q, Gu, L,Tang, W Z (2020) Effects of acid/alkali pretreatments on lignocellulosic biomass mono-digestion and its co-digestion with waste activated sludge. Journal of Cleaner Production 277: 123998.

Cornejo, A, Alegria-Dallo, I, Garcia-Yoldi, I, Sarobe, I, Sanchez, D, Otazu, E, Funcia, I, Gil, M J,MartinezMerino, V (2019) Pretreatment and enzymatic hydrolysis for the efficient production of glucose and furfural from wheat straw, pine and poplar chips. Bioresour Technol 288: 121583.

De Carvalho, J C, Magalhaes, A I, Jr., de Melo Pereira, G V, Medeiros, A B P, Sydney, E B, Rodrigues, C, Aulestia, D T M, de Souza Vandenberghe, L P, Soccol, V T,Soccol, C R (2020) Microalgal biomass pretreatment for integrated processing into biofuels, food, and feed. Bioresour Technol 300: 122719.

Diak, J,Örmeci, B (2016) Individual and Combined Effects of Freeze-Thaw and Ferrate(VI) Oxidation for the Treatment and Dewatering of Wastewater Sludges. Water, Air, \& Soil Pollution 227(9).

Dixon, C,Wilken, L R (2018) Green microalgae biomolecule separations and recovery. Bioresources and Bioprocessing 5(1).

Dumas, C, Silva Ghizzi Damasceno, G, Barakat, A, Carrère, H, Steyer, J-P,Rouau, X (2015) Effects of grinding processes on anaerobic digestion of wheat straw. Industrial Crops and Products 74: 450-456.

Fan, Y V, Klemeš, J J, Walmsley, T G,Perry, S (2019) Minimising energy consumption and environmental burden of freight transport using a novel graphical decision-making tool. Renewable and Sustainable Energy Reviews 114: 109335.

Ferreira, L C, Donoso-Bravo, A, Nilsen, P J, Fdz-Polanco, F,Perez-Elvira, S I (2013) Influence of thermal pretreatment on the biochemical methane potential of wheat straw. Bioresour Technol 143: 251-257.

Gao, W, Smith, D W,Li, Y (2006) Natural freezing as a wastewater treatment method: E. coli inactivation capacity. Water Res 40(12): 2321-2326.

Ge, X, Xu, F,Li, Y (2016) Solid-state anaerobic digestion of lignocellulosic biomass: Recent progress and perspectives. Bioresource Technology 205: 239-249.

Giuliano, A, Bari, I, Motola, V, Pierro, N, Giocoli, A,Barletta, D (2019) Techno-environmental Assessment of Two Biorefinery Systems to Valorize the Residual Lignocellulosic Biomass of the Basilicata Region. Mathematical Modelling of Engineering Problems 6(3): 317-323.

Gruber-Brunhumer, M R, Jerney, J, Zohar, E, Nussbaumer, M, Hieger, C, Bromberger, P, Bochmann, G, Jirsa, F, Schagerl, M, Obbard, J P, Fuchs, W,Drosg, B (2016) Associated effects of storage and mechanical pre- 
treatments of microalgae biomass on biomethane yields in anaerobic digestion. Biomass and Bioenergy 93: 259-268.

$\mathrm{Gu}, \mathrm{Y}, \mathrm{Zhang}, \mathrm{Y}, \mathrm{Zhou}, \mathrm{X}(2015)$ Effect of $\mathrm{Ca}(\mathrm{OH}) 2$ pretreatment on extruded rice straw anaerobic digestion. Bioresour Technol 196: 116-122.

Huiliñir, C, Quintriqueo, A, Antileo, C,Montalvo, S (2014) Methane production from secondary paper and pulp sludge: Effect of natural zeolite and modeling. Chemical Engineering Journal 257: 131-137.

Jackowiak, D, Bassard, D, Pauss, A,Ribeiro, T (2011) Optimisation of a microwave pretreatment of wheat straw for methane production. Bioresour Technol 102(12): 6750-6756.

Jeong, H-S, Jang, S-K, Kim, H-Y, Yeo, H, Choi, J W,Choi, I-G (2016) Effect of freeze storage on hemicellulose degradation and enzymatic hydrolysis by dilute-acid pretreatment of Mongolian oak. Fuel 165: 145-151.

Kainthola, J, Kalamdhad, A S, Goud, V V,Goel, R (2019) Fungal pretreatment and associated kinetics of rice straw hydrolysis to accelerate methane yield from anaerobic digestion. Bioresource Technology 286 : 121368.

Karthikeyan, O P, Trably, E, Mehariya, S, Bernet, N, Wong, J W C,Carrere, H (2018) Pretreatment of food waste for methane and hydrogen recovery: A review. Bioresour Technol 249: 1025-1039.

Kinnunen, V, Craggs, R,Rintala, J (2014) Influence of temperature and pretreatments on the anaerobic digestion of wastewater grown microalgae in a laboratory-scale accumulating-volume reactor. Water Res 57: 247-257.

Kumar, S, Gandhi, P, Yadav, M, Paritosh, K, Pareek, N,Vivekanand, V (2019) Weak alkaline treatment of wheat and pearl millet straw for enhanced biogas production and its economic analysis. Renewable Energy 139: 753-764.

Kumari, D,Singh, R (2018) Pretreatment of lignocellulosic wastes for biofuel production: A critical review. Renewable and Sustainable Energy Reviews 90: 877-891.

$\mathrm{Li}$, J, Wachemo, A C, Yuan, H, Zuo, X,Li, X (2019) Natural freezing-thawing pretreatment of corn stalk for enhancing anaerobic digestion performance. Bioresour Technol 288: 121518.

Li, L, He, Q, Zhao, X, Wu, D, Wang, X,Peng, X (2018) Anaerobic digestion of food waste: Correlation of kinetic parameters with operational conditions and process performance. Biochemical Engineering Journal 130: 1-9.

Li, W, Khalid, H, Zhu, Z, Zhang, R, Liu, G, Chen, C,Thorin, E (2018) Methane production through anaerobic digestion: Participation and digestion characteristics of cellulose, hemicellulose and lignin. Applied Energy 226: 1219-1228. 
Li, Y, Jin, Y, Li, H, Borrion, A, Yu, Z,Li, J (2018) Kinetic studies on organic degradation and its impacts on improving methane production during anaerobic digestion of food waste. Applied Energy 213: 136-147.

Liu, T, Zhou, X, Li, Z, Wang, X,Sun, J (2019) Effects of liquid digestate pretreatment on biogas production for anaerobic digestion of wheat straw. Bioresour Technol 280: 345-351.

Liu, X R, Huang, X D, Wu, Y X, Xu, Q X, Du, M T, Wang, D B, Yang, Q, Liu, Y W, Ni, B J, Yang, G J, Yang, F,Wang, Q L (2020) Activation of nitrite by freezing process for anaerobic digestion enhancement of waste activated sludge: Performance and mechanisms. Chemical Engineering Journal 387.

Liu, X Y, Ding, H B, Sreeramachandran, S, Stabnikova, O,Wang, J Y (2008) Enhancement of food waste digestion in the hybrid anaerobic solid-liquid system. Water Sci Technol 57(9): 1369-1373.

Martín, M A, Fernández, R, Gutiérrez, M C,Siles, J A (2018) Thermophilic anaerobic digestion of pre-treated orange peel: Modelling of methane production. Process Safety and Environmental Protection 117: 245253.

Montusiewicz, A, Lebiocka, M, Rozej, A, Zacharska, E,Pawlowski, L (2010) Freezing/thawing effects on anaerobic digestion of mixed sewage sludge. Bioresour Technol 101(10): 3466-3473.

Nguyen, D D, Jeon, B-H, Jeung, J H, Rene, E R, Banu, J R, Ravindran, B, Vu, C M, Ngo, H H, Guo, W,Chang, S W (2019) Thermophilic anaerobic digestion of model organic wastes: Evaluation of biomethane production and multiple kinetic models analysis. Bioresource Technology 280: 269-276.

Niu, J L, Liu, L,Zhang, Q G (2012) Effect of Biogas Production Characteristics of Dry Anaerobic Fermentation of Wheat Straw Pretreated by a Microbial Community with High Cellulose-Degradation Ability. Advanced Materials Research 347-353: 2996-3000.

Panigrahi, S, Sharma, H B,Dubey, B K (2020) Anaerobic co-digestion of food waste with pretreated yard waste: A comparative study of methane production, kinetic modeling and energy balance. Journal of Cleaner Production 243.

Paul, S,Dutta, A (2018) Challenges and opportunities of lignocellulosic biomass for anaerobic digestion. Resources, Conservation and Recycling 130: 164-174.

Phalakornkule, C, Nuchdang, S, Khemkhao, M, Mhuantong, W, Wongwilaiwalin, S, Tangphatsornruang, S, Champreda, V, Kitsuwan, J,Vatanyoopaisarn, S (2017) Effect of freeze-thaw process on physical properties, microbial activities and population structures of anaerobic sludge. Journal of Bioscience and Bioengineering 123(4): 474-481.

Phuttaro, C, Sawatdeenarunat, C, Surendra, K C, Boonsawang, P, Chaiprapat, S,Khanal, S K (2019) Anaerobic digestion of hydrothermally-pretreated lignocellulosic biomass: Influence of pretreatment temperatures, inhibitors and soluble organics on methane yield. Bioresource Technology 284: 128-138. 
Qi, N, Hu, X, Xin, X, Ye, S, Fu, Z,Zhao, X (2020) Mechanisms of biohydrogen recovery enhancement from peanut shell by $C$. guangxiense: Temperature pretreatment ranges from -80 to 100 degrees $C$. Bioresour Technol 304: 123026.

Rabemanolontsoa, H,Saka, S (2016) Various pretreatments of lignocellulosics. Bioresource Technology 199: 83-91.

Rahman, M A, Møller, H B, Saha, C K, Alam, M M, Wahid, R,Feng, L (2018) Anaerobic co-digestion of poultry droppings and briquetted wheat straw at mesophilic and thermophilic conditions: Influence of alkali pretreatment. Renewable Energy 128: 241-249.

Rajput, A A, Zeshan,Visvanathan, C (2018) Effect of thermal pretreatment on chemical composition, physical structure and biogas production kinetics of wheat straw. J Environ Manage 221: 45-52.

Risberg, K, Sun, L, Leven, L, Horn, S J,Schnurer, A (2013) Biogas production from wheat straw and manure-impact of pretreatment and process operating parameters. Bioresour Technol 149: 232-237.

Rodriguez, C, Alaswad, A, Benyounis, K Y,Olabi, A G (2017) Pretreatment techniques used in biogas production from grass. Renewable and Sustainable Energy Reviews 68: 1193-1204.

Rodriguez, C, Alaswad, A, El-Hassan, Z,Olabi, A G (2017) Mechanical pretreatment of waste paper for biogas production. Waste Management 68: 157-164.

Rooni, V, Raud, M,Kikas, T (2017) The freezing pre-treatment of lignocellulosic material: A cheap alternative for Nordic countries. Energy 139: 1-7.

Rouches, E, Escudie, R, Latrille, E,Carrere, H (2019) Solid-state anaerobic digestion of wheat straw: Impact of $\mathrm{S} / \mathrm{I}$ ratio and pilot-scale fungal pretreatment. Waste Manag 85: 464-476.

Savoo, S,Mudhoo, A (2018) Biomethanation macrodynamics of vegetable residues pretreated by lowfrequency microwave irradiation. Bioresour Technol 248(Pt A): 280-286.

Shen, J, Zheng, Q, Zhang, R, Chen, C,Liu, G (2019) Co-pretreatment of wheat straw by potassium hydroxide and calcium hydroxide: Methane production, economics, and energy potential analysis. $\mathrm{J}$ Environ Manage 236: 720-726.

Shetty, D J, Kshirsagar, P, Tapadia-Maheshwari, S, Lanjekar, V, Singh, S K,Dhakephalkar, P K (2017) Alkali pretreatment at ambient temperature: A promising method to enhance biomethanation of rice straw. Bioresour Technol 226: 80-88.

Smichi, N, Messaoudi, Y, Moujahed, N,Gargouri, M (2016) Ethanol production from halophyte Juncus maritimus using freezing and thawing biomass pretreatment. Renewable Energy 85: 1357-1361. 
Solarte-Toro, J C, Romero-García, J M, Martínez-Patiño, J C, Ruiz-Ramos, E, Castro-Galiano, E,CardonaAlzate, C A (2019) Acid pretreatment of lignocellulosic biomass for energy vectors production: A review focused on operational conditions and techno-economic assessment for bioethanol production. Renewable and Sustainable Energy Reviews 107: 587-601.

Sun, C, Liu, R, Cao, W, Li, K,Wu, L (2017) Optimization of Sodium Hydroxide Pretreatment Conditions to Improve Biogas Production from Asparagus Stover. Waste and Biomass Valorization 10(1): 121-129.

Sun, F, Xiao, K, Zhu, W, Withanage, N,Zhou, Y (2018) Enhanced sludge solubilization and dewaterability by synergistic effects of nitrite and freezing. Water Research 130: 208-214.

Theuretzbacher, F, Lizasoain, J, Lefever, C, Saylor, M K, Enguidanos, R, Weran, N, Gronauer, A,Bauer, A (2015) Steam explosion pretreatment of wheat straw to improve methane yields: investigation of the degradation kinetics of structural compounds during anaerobic digestion. Bioresour Technol 179: 299305.

Tian, S, Zhao, R,Chen, Z (2018) Review of the pretreatment and bioconversion of lignocellulosic biomass from wheat straw materials. Renewable and Sustainable Energy Reviews 91: 483-489.

Tian, W, Chen, Y, Shen, Y, Zhong, C, Gao, M, Shi, D, He, Q,Gu, L (2020) Effects of hydrothermal pretreatment on the mono- and co-digestion of waste activated sludge and wheat straw. Sci Total Environ 732: 139312.

Veluchamy, C,Kalamdhad, A S (2017) Enhanced methane production and its kinetics model of thermally pretreated lignocellulose waste material. Bioresour Technol 241: 1-9.

Veluchamy, C, Raju, V W,Kalamdhad, A S (2018) Electrohydrolysis pretreatment for enhanced methane production from lignocellulose waste pulp and paper mill sludge and its kinetics. Bioresour Technol 252: $52-58$.

Wang, K, Yun, S, Xing, T, Li, B, Abbas, Y,Liu, X (2021) Binary and ternary trace elements to enhance anaerobic digestion of cattle manure: Focusing on kinetic models for biogas production and digestate utilization. Bioresource Technology 323: 124571.

Ware, A,Power, N (2017) Modelling methane production kinetics of complex poultry slaughterhouse wastes using sigmoidal growth functions. Renewable Energy 104: 50-59.

Yao, Y, Huang, G, An, C, Chen, X, Zhang, P, Xin, X, Jian, S,Agnew, J (2020) Anaerobic digestion of livestock manure in cold regions: Technological advancements and global impacts. Renewable and Sustainable Energy Reviews 119.

You, Z, Pan, S-Y, Sun, N, Kim, H,Chiang, P-C (2019) Enhanced corn-stover fermentation for biogas production by $\mathrm{NaOH}$ pretreatment with $\mathrm{CaO}$ additive and ultrasound. Journal of Cleaner Production 238: 117813. 
Yu, D, Zhang, J, Chulu, B, Yang, M, Nopens, I,Wei, Y (2020) Ammonia stress decreased biomarker genes of acetoclastic methanogenesis and second peak of production rates during anaerobic digestion of swine manure. Bioresource Technology 317: 124012.

Yu, Q, Cui, S, Sun, C, Liu, R, Sarker, M, Guo, Z,Lai, R (2020) Synergistic Effects of Anaerobic Co-Digestion of Pretreated Corn Stover with Chicken Manure and Its Kinetics. Applied Biochemistry and Biotechnology.

Yu, Q, Liu, R, Li, K,Ma, R (2019) A review of crop straw pretreatment methods for biogas production by anaerobic digestion in China. Renewable and Sustainable Energy Reviews 107: 51-58.

Zabed, H M, Akter, S, Yun, J, Zhang, G, Zhang, Y,Qi, X (2020a) Biogas from microalgae Technologies, challenges and opportunities.

Zabed, H M, Akter, S, Yun, J, Zhang, G, Zhang, Y,Qi, X (2020b) Biogas from microalgae: Technologies, challenges and opportunities. Renewable and Sustainable Energy Reviews 117: 109503.

Zhang, K, Xu, R, Abomohra, A E-F, Xie, S, Yu, Z, Guo, Q, Liu, P, Peng, L,Li, X (2019) A sustainable approach for efficient conversion of lignin into biodiesel accompanied by biological pretreatment of corn straw. Energy Conversion and Management 199: 111928.

Zhong, W, Zhang, Z, Luo, Y, Sun, S, Qiao, W,Xiao, M (2011) Effect of biological pretreatments in enhancing corn straw biogas production. Bioresource Technology 102(24): 11177-11182.

Zou, H, Jiang, Q, Zhu, R, Chen, Y, Sun, T, Li, M, Zhai, J, Shi, D, Ai, H, Gu, L,He, Q (2020) Enhanced hydrolysis of lignocellulose in corn cob by using food waste pretreatment to improve anaerobic digestion performance. Journal of Environmental Management 254: 109830.

\section{Figures}




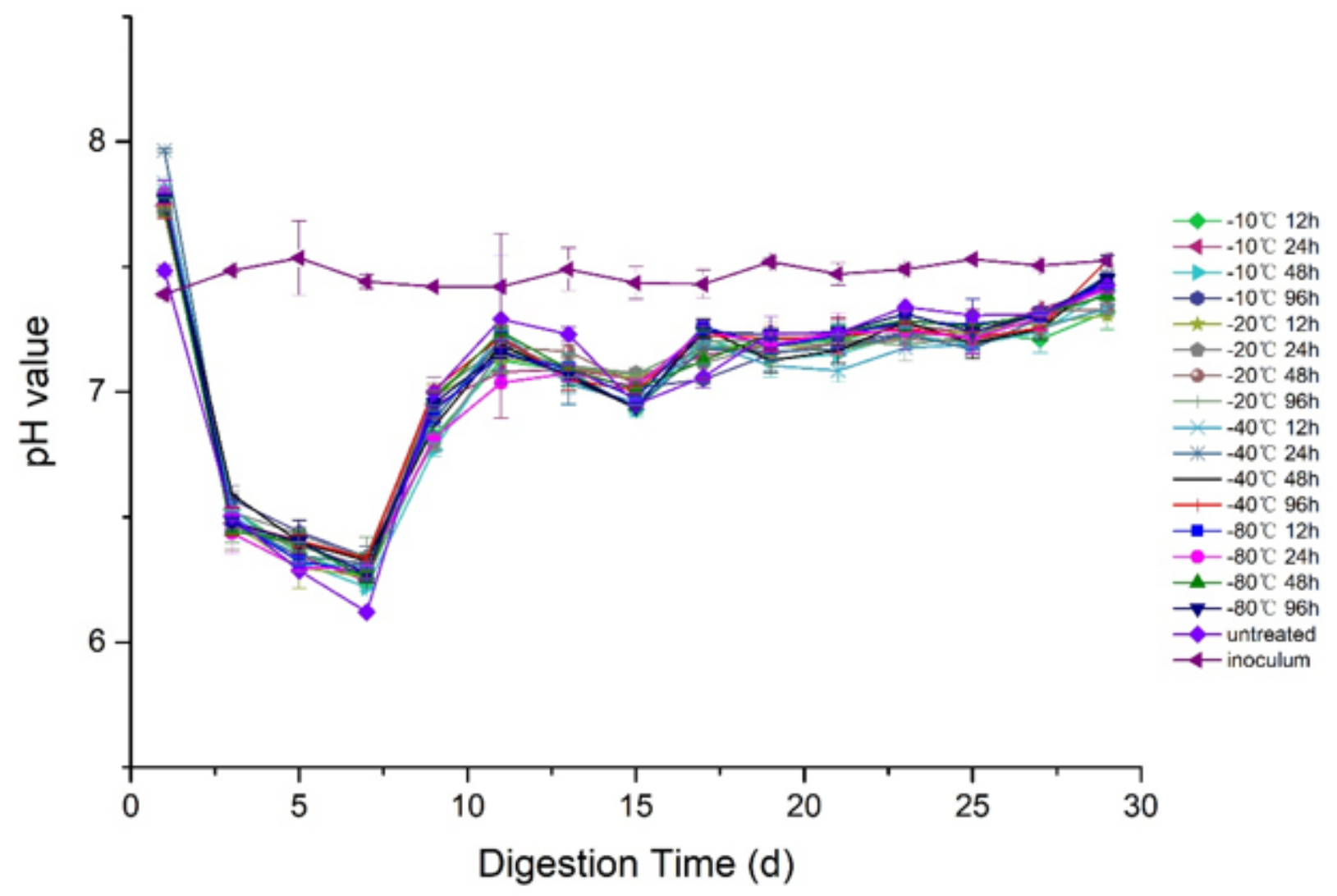

Figure 1

Change of $\mathrm{pH}$ value 


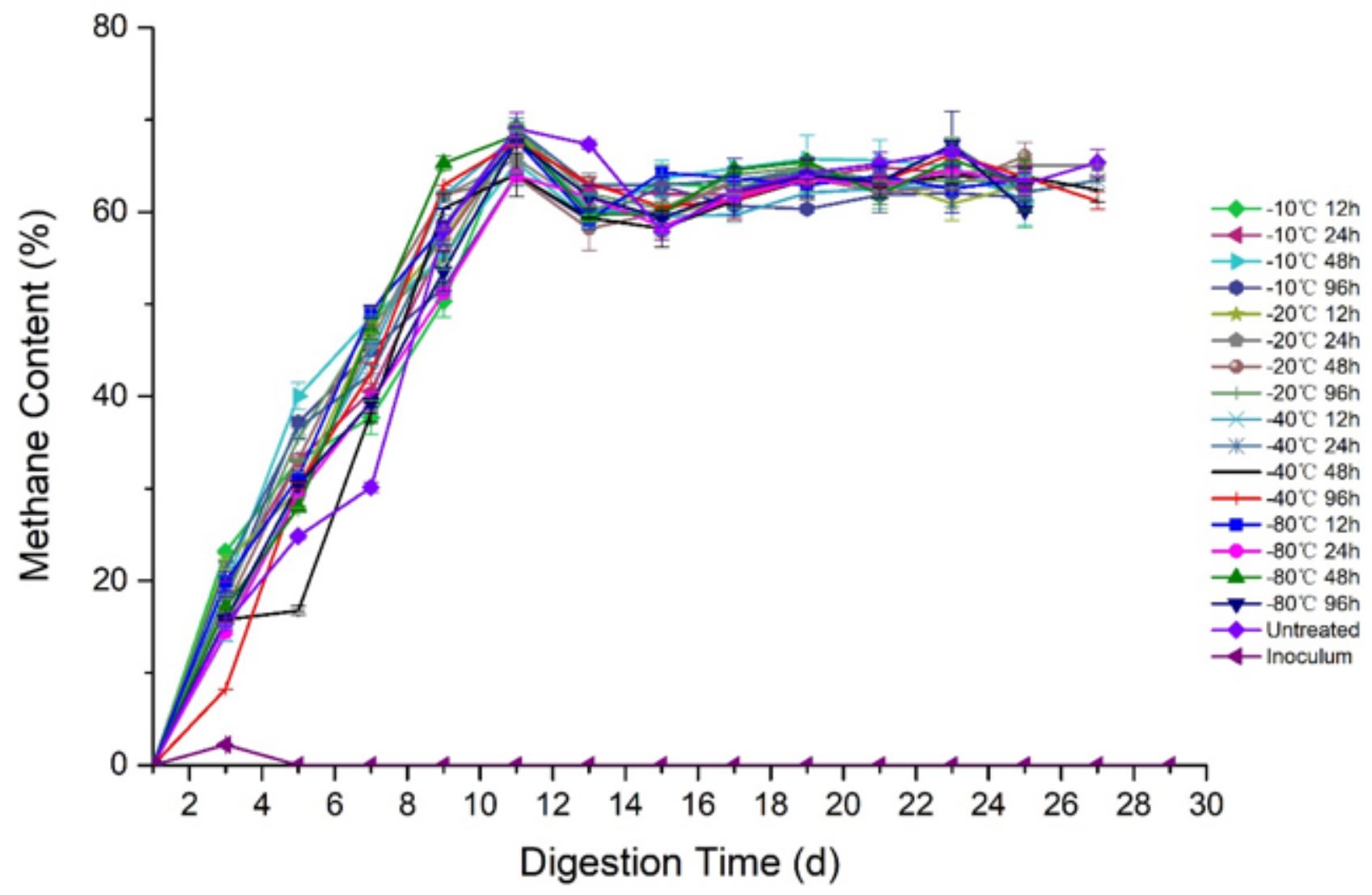

Figure 2

Methane Content of Wheat Straw (WS) 

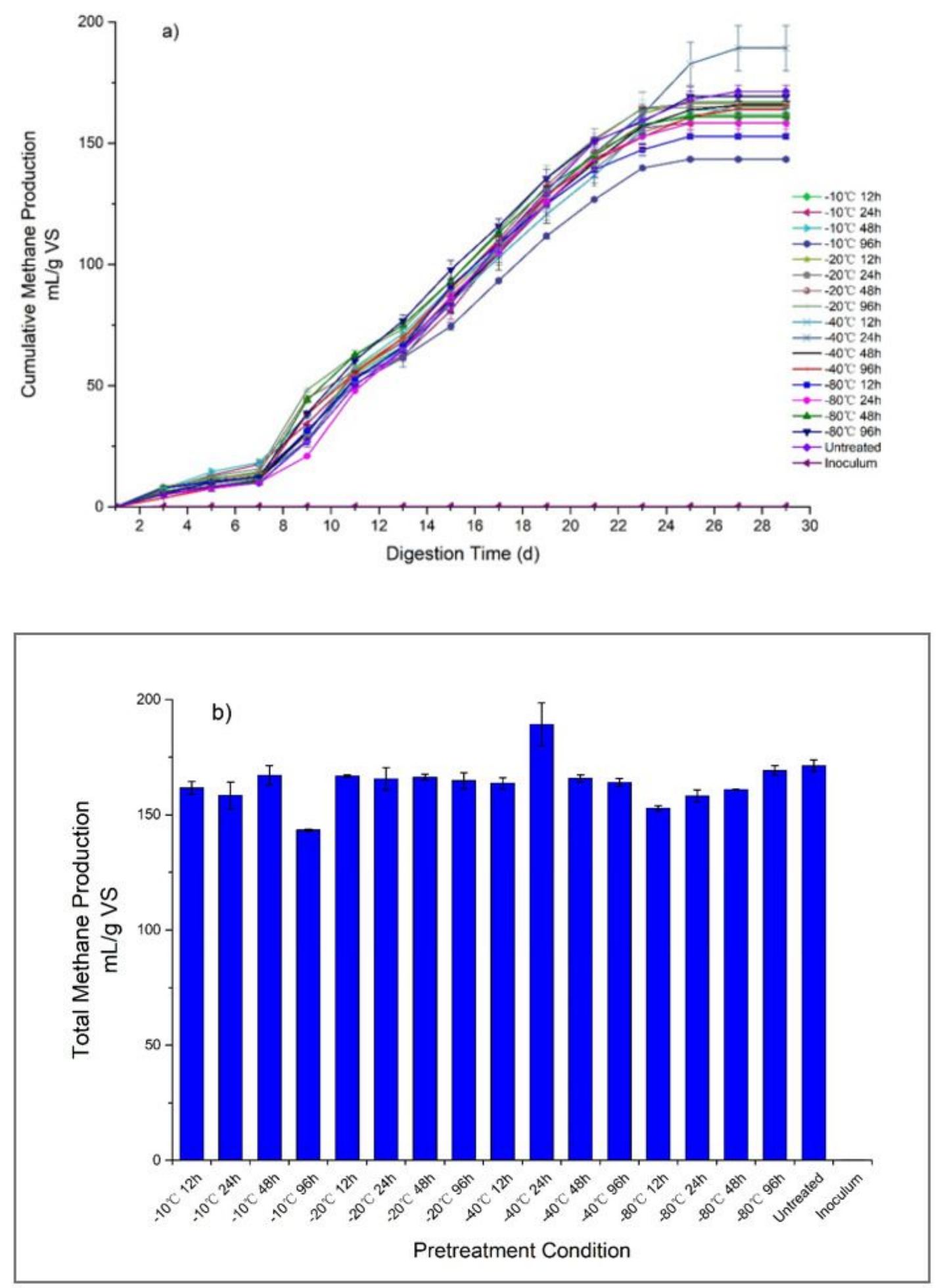

Figure 3

Methane production of WS, a): cumulative methane production; b): total methane production. 

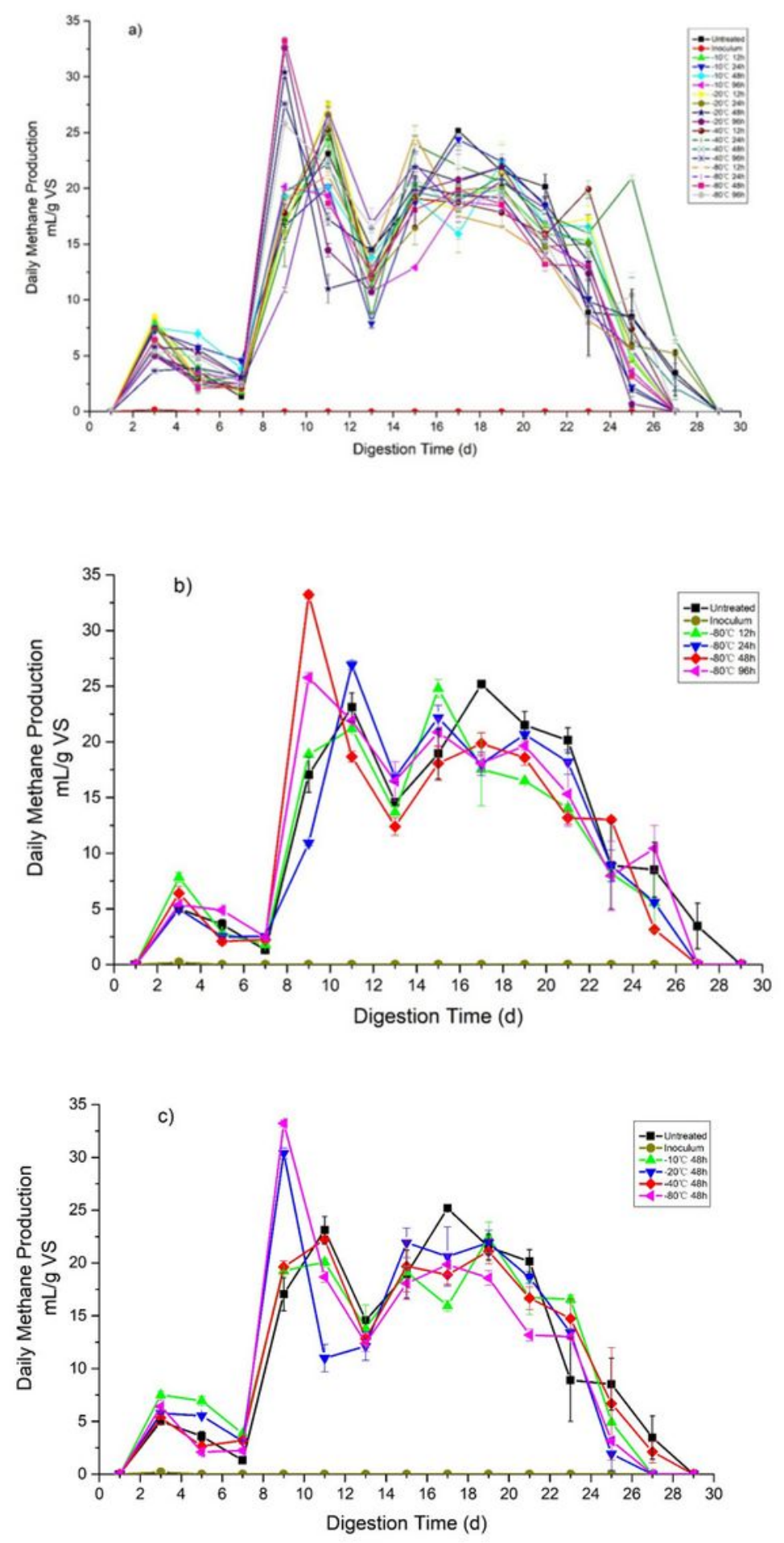

\section{Figure 4}

Daily methane production of all WS: a) all WS treated with different conditions; b) WS pretreated at $-80^{\circ} \mathrm{C}$; c) WS pretreated for $48 \mathrm{~h}$. 

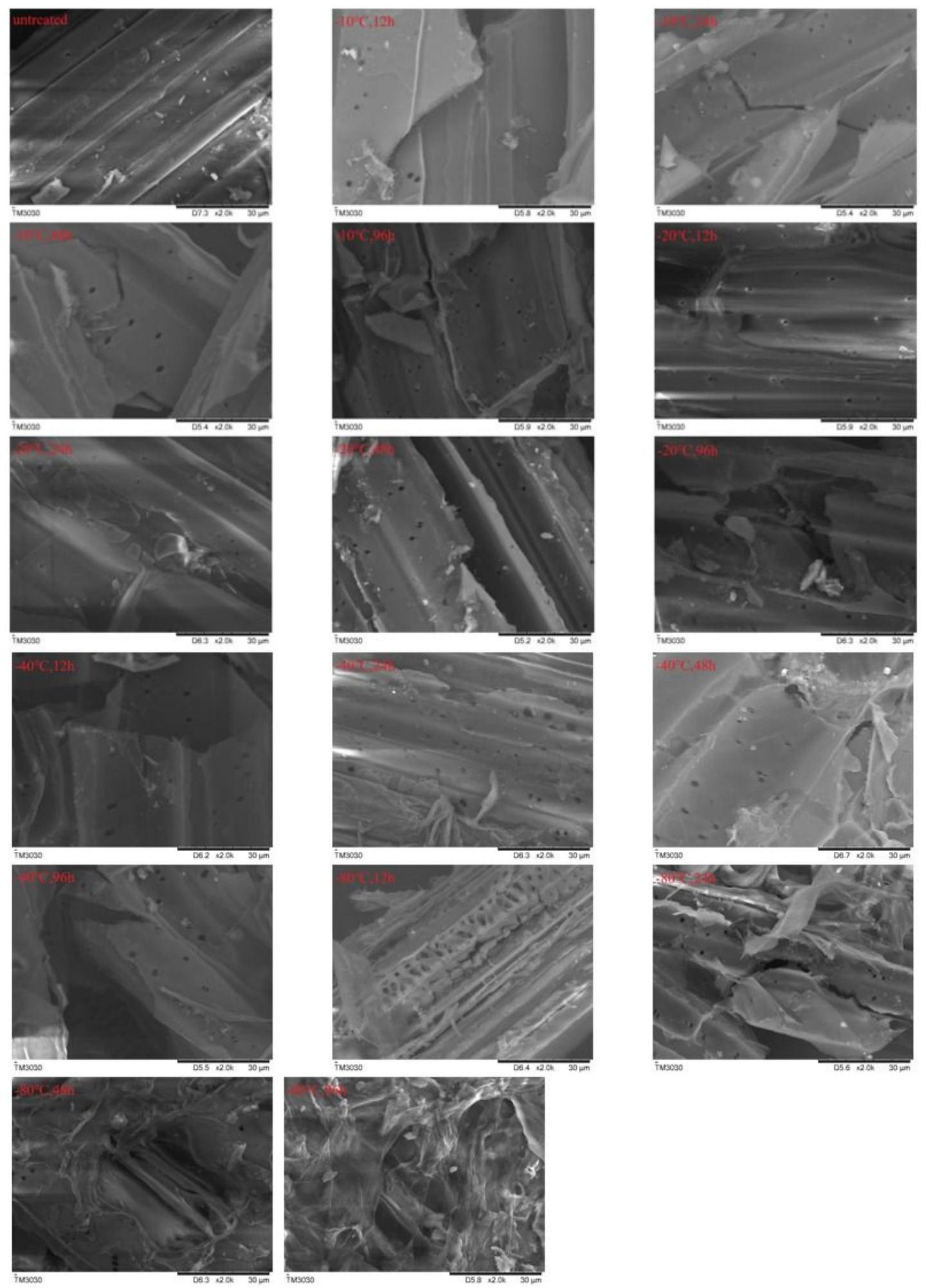

Figure 5

Scanning electron micrographs of WS 

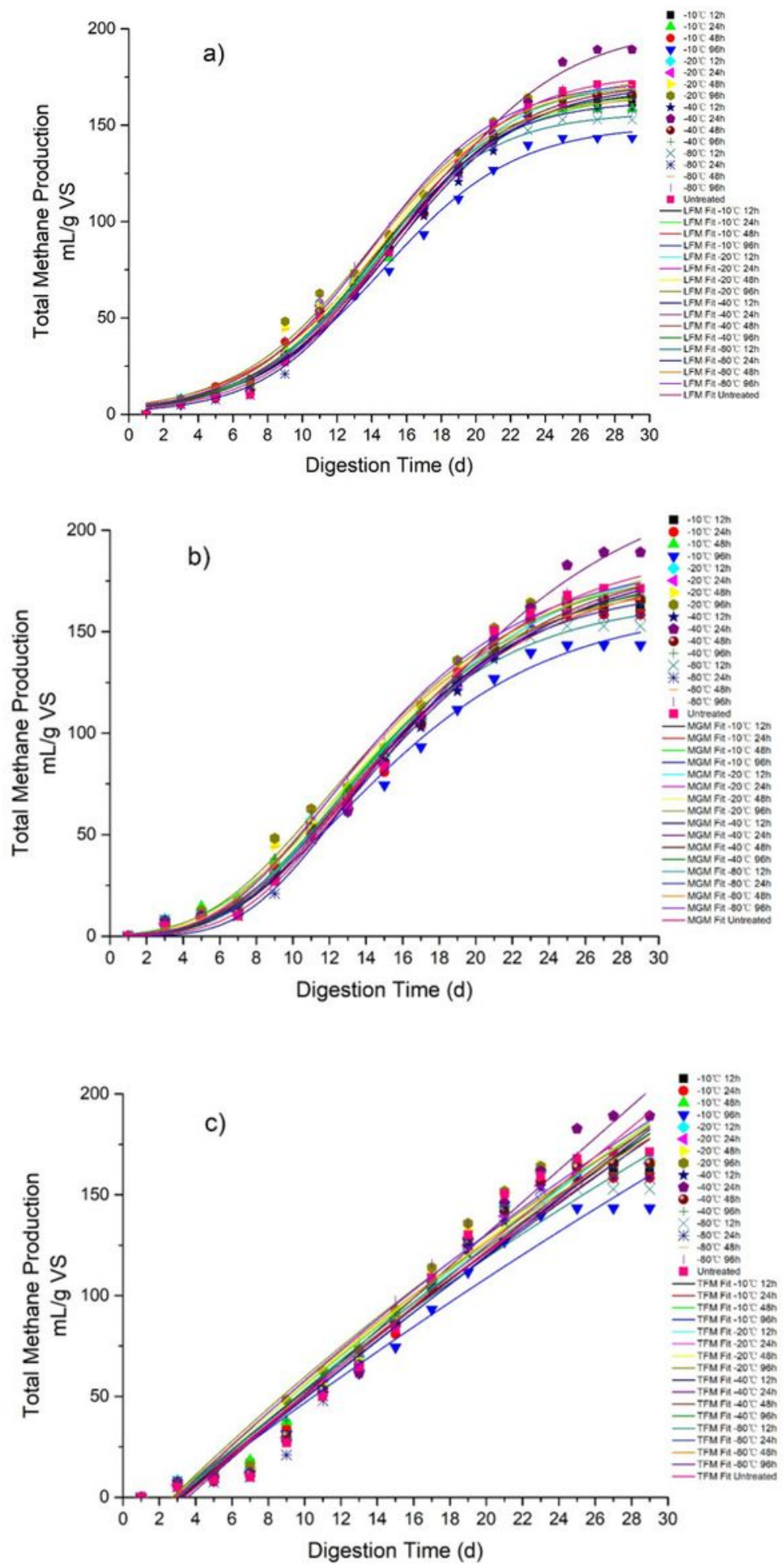

\section{Figure 6}

Model fitted with total methane production from AD of FT pretreated WS with different freezing condition, a): LFM; b): MGM; c): TFM. 


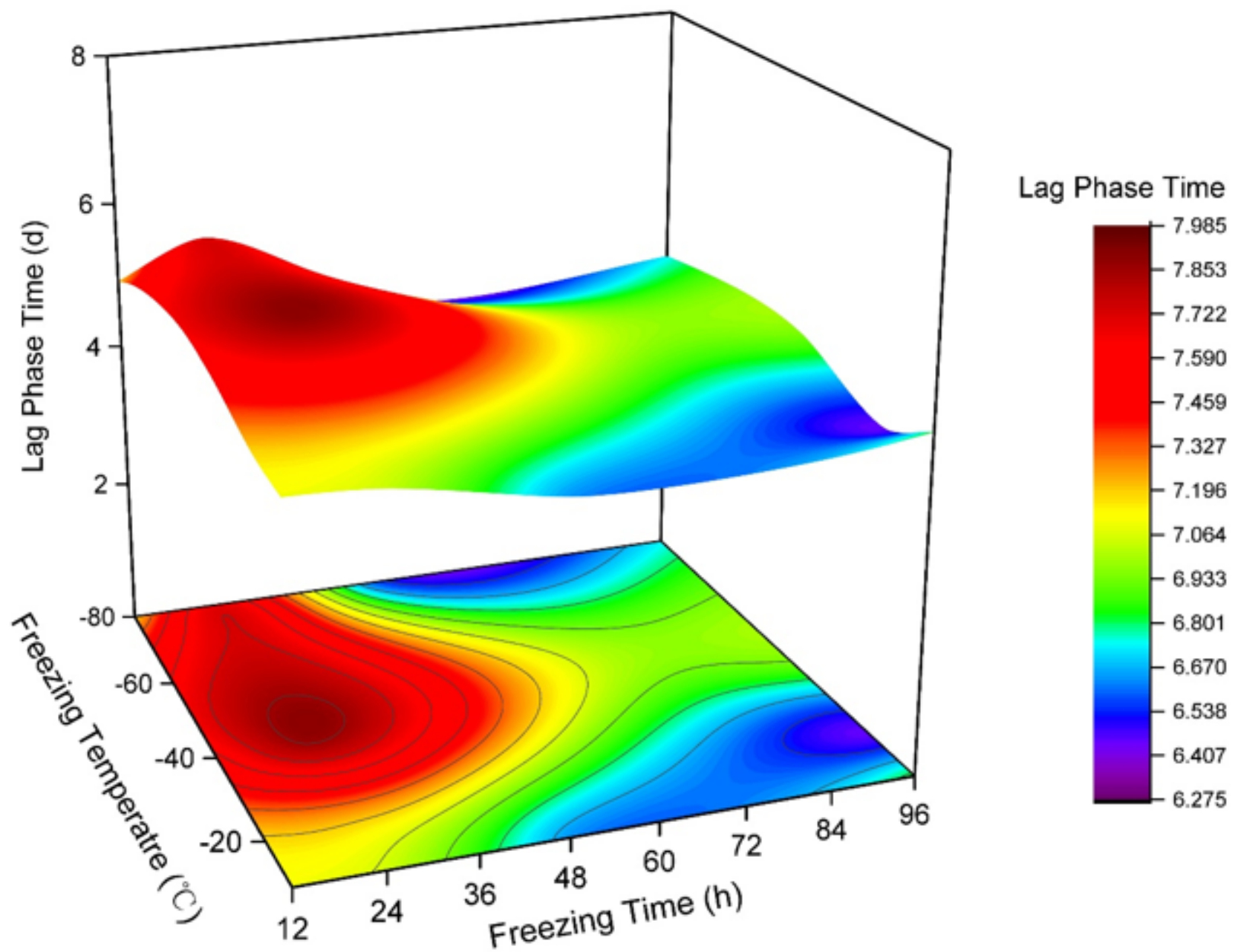

Figure 7

The influence of process parameters on lag phase time during FT pretreatments of WS 

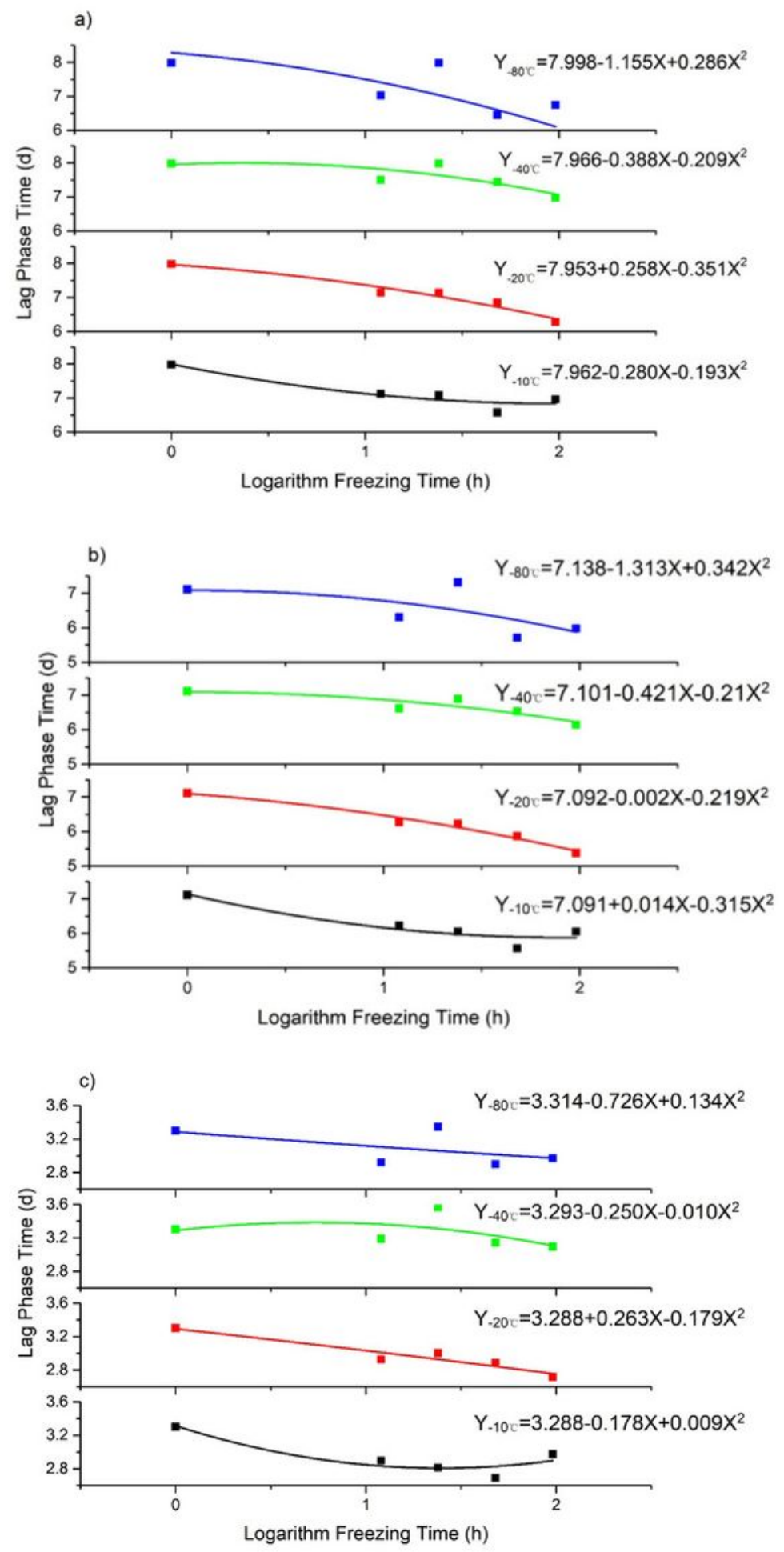

\section{Figure 8}

Effect of different freezing time on lag phase of AD囚a): LFM; b): MGM; c): TFM.

\section{Supplementary Files}

This is a list of supplementary files associated with this preprint. Click to download. 
- Graphicabstractzqr20210308.docx 